\title{
Pengaruh Latar Belakang Pendidikan dan Pemahaman Standar Akuntansi Keuangan Entitas Nirlaba terhadap Penyusunan dan Penyajian Laporan Keuangan
}

\author{
Ade Imam Muslim \\ imemmuslim81@gmail.com \\ Lediana Sufina \\ lediana_sufina@yahoo.com \\ STIE Ekuitas, Bandung
}

\begin{abstract}
Abstrack
This research aims to determine the effect of educational level and understanding accounting standards of non profit financial entity on the preparation and presentation financial statements. The population in this research is all mosques that hold financial records of Bandung Regency or Bandung City. The sample of research was taken incidentally with the respondent of finance department or doing the recording of finance in mosque as much as 30 mosque. The data collected is primary data through the spread of questionnaires both online and manual. Data processing technique is done through validity test, reliability, data conversion through Succesive Interval Method and hypothesis test through multiple regression analysis either partially or simultaneously. The result of this research shows that in general the compiler and reporter of the mosque's financial statements have not understood and know the term of PSAK. The preparation and presentation of financial statements in mosque entities still use single entry system. This system only records receipts and expenses. Meanwhile, the level of education and level of understanding of PSAK significantly influences the preparation and presentation of non-profit entity financial statements. This influence can be proved by the significance value of both variables that is 0.003 and 0.011 .
\end{abstract}

Keyword : Financial statements of nonprofit entities, PSAK. 


\section{PENDAHULUAN}

Mengacu kepada PSAK No. 01 Penyajian Laporan Keuangan, bahwa laporan keuangan harus memuhi karakteristik kwalitatif. Karakteristik kwalitatif yang harus dipenuhi oleh laporan keuangan sehingga dapat berguna bagi penggunanya terdiri dari dapat dipahami, relevan, materialitas, kendalan, penyajian jujur, substansi mengungguli bentuk, netralitas, pertimbangan sehat, kelengkapan, dan dapat dibandingkan.

Sebagai upaya mencapai karakteristik tersebut, maka laporan keuangan harus disusun sesuai dengan standar yang berlaku. Selain tuntutan karakteristik kwalitatif tersebut, entitas juga dituntut untuk memenuhi akuntabilitasnya dalam organisasi dan transaksi keuangan. Tidak hanya entitas bisnis, tetapi juga entitas nirlaba seperti lembaga agama juga dituntut untuk memenuhi akuntabilitas tersebut.

Selain tuntutan tersebut, mengacu kepada Petunjuk Teknis Penilaian Masjid Besar Nomor DJ.III/384 tahun 2016, bahwa dalam rangka tertib administrasi masjid, salah satu komponen penilaian masjid adalah adanya tertib administrasi termasuk pencatatan keuangan

Berdasarkan petunjuk teknis tersebut, kegiatan masjid akan dinilai dari tiga komponen, yaitu idarah, imarah, ri'ayah. Idarah terkait dengan pengelolaan manajemen masjid, visi, misi, moto pelayanan dan administrasi keuangan. Akuntansi merupakan salah upaya untuk memberikan dukungan sistem pencatatan sehingga memberikan tata kelola yang baik terhadap masjid. Imarah terkait kemakmuran, seperti remaja masjid, kegiatan pendidikan dan dakwah, dan sistem informasi masjid. Sedangkan ri'ayah terkait dengan pemeliharaan dan pemberdayaan masjid seperti fasilitas dan pemeliharaannya.

Standar Akuntansi Keuangan (SAK) yang mengatur entitas nirlaba seperti masjid terdiri dari PSAK 45 : Pelaporan Keuangan Entitas Nirlaba, PSAK 109 : Akuntansi Zakat Infak dan Shadaqah dan PSAK Entitas Tanpa Akuntabilitas Publik (ETAP). karena itu, dalam menyusun laporan keuangannya, masjid dapat mengacu kepada standar-standar tersebut.

Permasalahan utama yang muncul dalam akuntansi atau sistem pencatatan di masjid adalah bahwa pencatatannya masih menggunakan single entry system. Pencatatan single entry system merupakan sistem pencatatan di mana hanya melibatkan satu sisi pencatatan yaitu penerimaan dan pengeluaran kas. Sehingga yang menjadi perhatian adalah saldo kas. Seperti penelitian yang dilakukan oleh Andarsari (2016). Hasil penelitiannya menemukan bahwa dalam melakukan pencatatan masjid masih sangat sederhana dan hanya melibatkan penerimaan kas dan pengeluaran kas. Penelitian Rizky dan Padmono (2013) menyimpulkan bahwa selain pencatatan keuangan yang belum sesuai dengan PSAK, struktur organisasi dan wewenang juga belum efektif dilaksanakan.

Berdasarkan hasil on the spot di lapangan, masjid-masjid besar di Kabupaten Bandung belum sepenuhnya memahami dan menggunakan laporan keuangan. Masjid Besar Majalaya, misalnya, menurut sekretaris masjid Bpk. Haji Maman Kariman, laporan keuangan masih menggunakan sistem pencatatan single entry system dan masih sederhana. Begitu juga dengan Masjid Besar Al-Muhajirin, Margaasih, pencatatan keuangan masih sederhana dan dilaporkan di papan masjid.

Motivasi dari penelitian ini terutama didorong oleh permasalahan pencatatan keuangan di masjid dan permasalahan sumber daya manusia yang melakukan penyusunan laporan keuangan. Oleh karena itu, penulis akan meneliti tingkat pemahaman dan pendidikan pengurus masjid dalam menyusun laporan keuangannya. Permasalahan utama dalam penelitian ini adalah bagaimana tingkat pemahaman standar akuntansi keuangan entitas nirlaba dan tingkat pendidikan dapat mempenaruhi penyusunan dan penyajian laporan keuangan. 


\section{KERANGKA TEORITIS DAN HIPOTESIS}

\section{Organisasi Nirlaba}

Menurut Hasibuan (2010) organisasi merupakan suatu sistem perserikatan formal, berstruktur dan terkoordinasi dari sekelompok yang bekerja sama dalam mencapai tujuan tertentu. Organisasi hanya merupakan alat dan wadah saja. Menurut Mooney (1996) organisasi adalah bentuk setiap perserikatan manusia untuk mencapai tujuan bersama. Berdasarkan kedua pendapat tersebut, maka organisasi dapat disimpulkan sebagai suatu kumpulan atau perserikatan yang bersifat formal, terdiri dari orang orang yang berkoordinasi dan bekerjasama untuk mencapai tujuan yang telah ditetapkan.

Tujuan yang ingin dicapai dalam organisasi, dapat bersifat finansial atau non finansial. Menurut Mahsun (2006), tujuan dari organisasi terdiri dari Pure Profit Organization, Quasi Profit Organization, dan Quasi Non Profit Organization. Tujuan yang bersifat Pure Profit Organization merupakan tujuan organisasi dalam kaitannya dengan penjualan barang dan jasa untuk memperoleh laba atau keuntungan sebesarsesarnya, sehingga dapat dinikmati oleh pemilik. Tujuan yang bersifat Quasi Profit Organization, merupakan tujuan organisasi dalam kaitannya dengan penjualan barang dan jasa untuk memperoleh keuntungan, serta untuk mencapai tujuan-tujuan lainnya. Sementara itu, Quasi Non Profit Organization merupakan organisasi yang menyediakan barang dan jasa dengan tujuan untuk melayani dan meningkatkan kesejahteraan masyarakat.

Organisasi nirlaba sendiri jika mengacu kepada pendapat dari Nainggolan (2005) adalah lembaga atau organisasi nirlaba merupakan suatu lembaga atau kumpulan dari beberapa individu yang memiliki tujuan tertentu dan bekerja sama untuk mencapai tujuan tadi, dalam pelaksanaannya kegiatan yang mereka lakukan tidak berorientasi pada pemupukan laba atau kekayaan semata. Sedangkan menurut Anthony dan Young (2003) organisasi nirlaba sebagai organisasi yang tujuannya adalah sesuatu di luar menerima keuntungan untuk para pemiliknya, biasanya bertujuan untuk memberi pelayanan.
Dalam hal pertanggungjawaban keuangan, organisasi nirlaba tidak dapat memperoleh modal ekuitas dari para investor luar, kecuali modal ekuitas mereka donasikan.

\section{Klasifikasi Organisasi Nirlaba}

Wilson dan Kattelus (2004) memberikan klasifikasi organisasi nirlaba yang berlaku di Amerika Serikat. Organisasi nirlaba dikelompokkan menjadi dua kelompok yaitu organisasi nirlaba nonpemerintah dan organisasi nirlaba pemerintah. Organisasi nirlaba nonpemerintah terdiri dari organisasi nirlaba yang dikenai pajak dan organiasi nirlaba yang mendapat pengecualian pajak. Organisasi nirlaba yang mendapat pengecualian pajak terdiri dari organisasi kerjasama, sektor yang bebas seperti organsiasi keagamaan, organsiasi sosial dan badan amal baik dalam bentuk yayasan atau lembaga swadaya masyarakat.

\section{Tingkat Pemamahan}

Entitas nirlaba dapat menyusun laporan keuangan yang terdiri dari laporan posisi keuangan, laporan aktivitas, laporan arus kas dan catatan atas laporan keuangan. Selain itu, untuk entitas masjid yang menghimpun dana shodaqoh, infaq dan zakat, maka sesuai dengan PSAK 109 : Akuntansi Zakat, Infaq dan Shodaqoh, diharuskan menyusun laporan penggunaan dana Zakat, Infaq dan Shodaqoh.

Menurut Kamus Besar Indonesa (Poerwadarminta : 2006) paham mempunyai pengertian pandai dan mengerti benar. Sedangkan pemahaman, merupakan cara, proses dan perbuatan memahami atau memahamkan. Pemahaman dalam akuntansi entitas nirlaba berarti bahwa seseorang pandai dan mengerti benar tentang akuntansi entitas nirlaba, dari mulai proses transaksi sampai penyusunan laporan keuangan sesuai dengan PSAK 45, PSAK 109 dan SAK ETAP.

\section{Penyusunan dan Penyajian Laporan Keuangan Entitas Nirlaba}


Laporan keuangan untuk entitas nirlaba terdiri atas laporan posisi keuangan (neraca), laporan aktivitas, laporan arus kas, dan catatan atas laporan keuangan. Laporan keuangan tersebut berbeda dengan laporan keuangan untuk entitas bisnis pada umumnya (PSAK 45 Paragrap 03 dan 04). Tujuan utama laporan keuangan adalah menyediakan informasi yang relevan untuk memenuhi kepentingan para penyumbang, anggota entitas nirlaba, kreditor, dan pihak lain yang menyediakan sumber daya bagi entitas nirlaba. (PSAK 45 Paragrap 06).

Secara rinci, tujuan laporan keuangan, termasuk catatan atas laporan keuangan, adalah untuk menyajikan informasi mengenai: (a) jumlah dan sifat aset, liabilitas, dan aset neto entitas nirlaba; (b) pengaruh transaksi, peristiwa, dan situasi lainnya yang mengubah nilai dan sifat aset neto (c) jenis dan jumlah arus masuk dan arus keluar sumber daya dalam satu periode dan hubungan antara keduanya; (d) cara entitas nirlaba mendapatkan dan membelanjakan kas, memperoleh pinjaman dan melunasi pinjaman, dan faktor lainnya yang berpengaruh pada likuiditasnya; (e) usaha jasa entitas nirlaba (PSAK 45 Paragrap 08).

\section{METODOLOGI}

Metode penelitian yang digunakan dalam penelitian ini merupakan penelitian deskriptif dan verifikasit. Menurut Sujana dan Ibrahim (2007) penelitian deskriptif merupakan penelitian yang berupaya untuk menggambarkan kejadian atau fenomena apa adanya, tanpa bermaksud mengambil kesimpulan secara umum. Sementara itu, teknik analisis data digunakan teknik analisis regresi berganda.

\section{Populasi dan Sampel}

Populasi dalam penelitian ini adalah seluruh masjid di Kabupaten Bandung. Terdapat 4.875 Masjid di Kabupaten Bandung yang terdaftar di Kementerian Agama. Sementara itu, sampel dalam penelitian ini sampel ditentukan secara insidental, yaitu sampel yang ditentukan oleh peneliti secara kebetulan (insidental) sesuai dengan kebutuhan penelitian. Total sampel yang diambil untuk keperluan penelitian ini adalah 30 masjid yang tersebar di Kabupaten Bandung dan Kota Bandung.

\section{Teknik Pengumpulan Data}

Data yang dikumpulkan merupakan data primer yang diperoleh melalui penyebaran kuesioner. Responden dalam penelitian ini adalah pengurus masjid di Kabupaten Bandung. Kuesioner yang disusun, mengikuti skala Likert. 
Pengaruh...(Ade, Lediana)

\section{Kerangka Pemikiran}

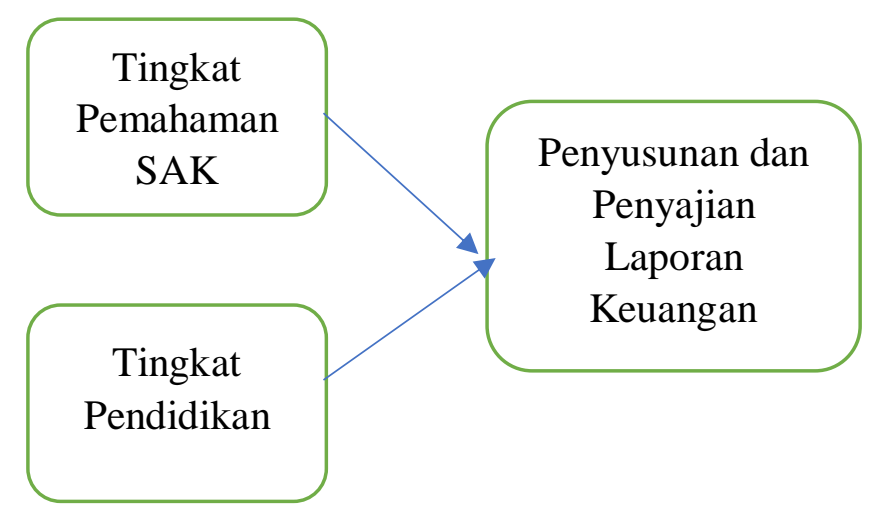

Gambar 1 : Kerangka Pemikiran 
Operasionalisasi Variabel

Tabel 1

Operasionalisasi Varial

\begin{tabular}{llll}
\hline 1 & 0.630 & 0.3610 & Valid \\
2 & 0.400 & 0.3610 & Valid \\
3 & 0.562 & 0.3610 & Valid \\
4 & 0.645 & 0.3610 & Valid \\
\hline
\end{tabular}

Sumber : SPSS, data diolah

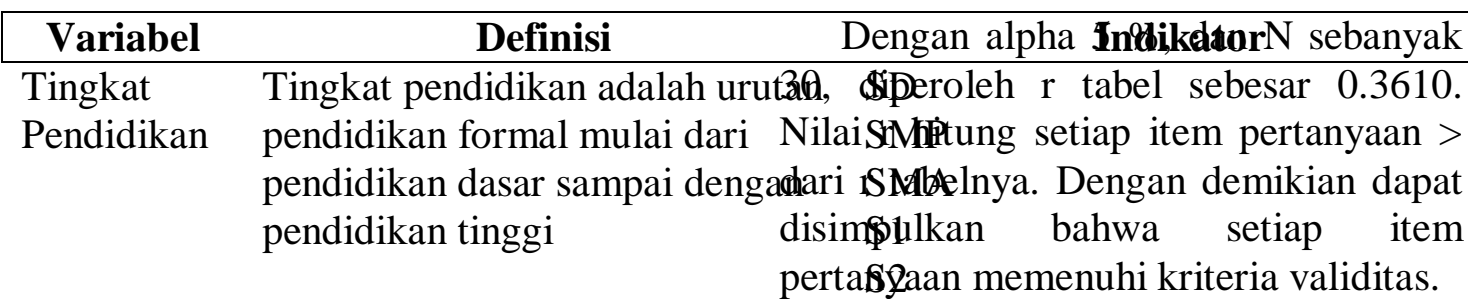

Tingkat Pandai dan mengerti benar

a. Tingkat pemahaman terhadap

Pemahaman tentang akuntansi entitas nirlabu,ji relidbilptonsen lipstramkauangimglkatn SAK dari mulai proses transaksi pemahanPaninstipnellan ndkungiansiitas nirlaba sampai penyusunan laporan b. Tingkat pemahaman terhadap keuangan sesuai dengan PSAK pđagek AanUjüisReliabsilitasporan 45, PSAK 109 dan SAK ETAP.Instr Creunbagedn entitabehirlaßaliabil

Penyajian Menyampaikan laporan umenl. Isapłpha Posisi Keuangàtas

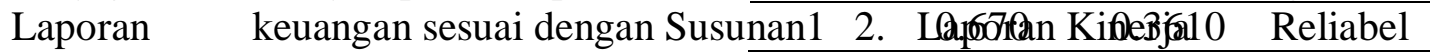


Keuangan Entitas Nirlaba

4. Laporan Penggunaan Dana Zakat Dengdana\$bladaror, dan N sebanyak 30, Wiperoleh $r$ tabel sebesar 0.3610 . Nilai Cronbach's Alpha diperoleh sebesar 0.670. Nilai Cronbach's Alpha >

\section{HASIL DAN PEMBAHASAN}

Uji validitas instrumen tingkat pemahaman standar akuntansi

Tabel 2 : Uji Validitas

\begin{tabular}{cccc}
\hline $\begin{array}{c}\text { Instru } \\
\text { men }\end{array}$ & $\begin{array}{c}\mathrm{r} \\
\text { hitung }\end{array}$ & r tabel & $\begin{array}{c}\text { Validi } \\
\text { tas }\end{array}$ \\
\hline 1 & 0.551 & 0.3610 & Valid \\
2 & 0.531 & 0.3610 & Valid \\
3 & 0.688 & 0.3610 & Valid \\
4 & 0.403 & 0.3610 & Valid \\
5 & 0.401 & 0.3610 & Valid \\
6 & 0.378 & 0.3610 & Valid \\
\hline
\end{tabular}

Sumber : SPSS, data diolah

Uji validitas instrumen penyusunan dan penyajian laporan keuangan

Tabel 3 : Uji Validitas

\begin{tabular}{cccc}
\hline $\begin{array}{c}\text { Instru } \\
\text { men }\end{array}$ & $\mathrm{r}$ hitung & $\mathrm{r}$ tabel & $\begin{array}{c}\text { Validit } \\
\text { as }\end{array}$ \\
\hline
\end{tabular}
dari nilai $r$ tabel, sehingga item pertanyaan memenuhi kriteria reliabel. Uji reliabilitas instrumen penyusunan dan penyajian laporan keuangan

Tabel 5 : Uji Reliabilitas

\begin{tabular}{cccc}
\hline $\begin{array}{c}\text { Instr } \\
\text { umen }\end{array}$ & $\begin{array}{c}\text { Cronbac' } \\
\text { s Alpha }\end{array}$ & r tabel & $\begin{array}{c}\text { Reliabili } \\
\text { tas }\end{array}$ \\
\hline 1 & 0.689 & 0.3610 & Reliabel \\
\hline Sumber : SPSS, data diolah &
\end{tabular}

Dengan alpha $5 \%$, dan $\mathrm{N}$ sebanyak 30, diperoleh $\mathrm{r}$ tabel sebesar 0.3610 . Nilai Cronbach's Alpha diperoleh sebesar 0.689. Nilai Cronbach's Alpha > dari nilai $r$ tabel, sehingga item pertanyaan memenuhi kriteria reliabel.

\section{Uji Asumsi Klasik Uji Normalitas}

Tabel 6 : Uji Normalitas 


\begin{tabular}{ccc}
\hline $\mathrm{N}$ & $\begin{array}{c}\text { Kolmogorov- } \\
\text { Smirnov Z }\end{array}$ & $\begin{array}{c}\text { Asymp. } \\
\text { Sig. (2- } \\
\text { tailed) }\end{array}$ \\
\hline 30 & 0.445 & 0.989 \\
\hline
\end{tabular}

Sumber : Data diolah

Berdasarkan tabel tersebut, diperoleh nilai sig sebesar $0.989>0.05$. Dengan demikian, data memenuhi syarat normalitas.

Uji Multikolinieritas

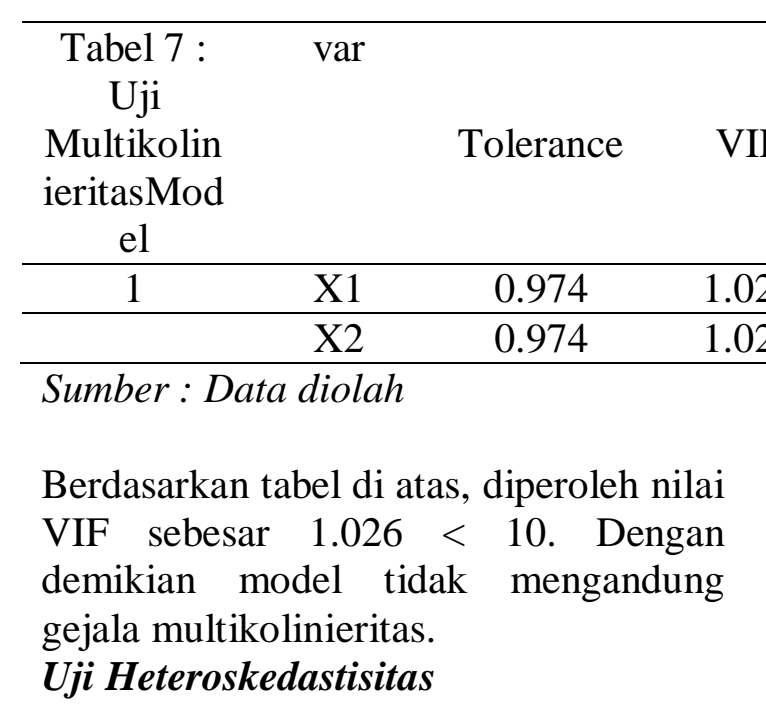

Tabel 8 : Uji Heteroskedastisitas

\begin{tabular}{cc}
\hline Model & Sig \\
\hline $\mathrm{x} 1$ & 0.610 \\
\hline $\mathrm{X} 2$ & 0.198 \\
\hline
\end{tabular}

Sumber : Data diolah

Berdasarkan tabel di atas, diperoleh nilai Sig untuk var x1 sebesar $0.610>0.05$, sehingga model terbebas dari heteroskedastisitas dan untuk var x2 sebesar $0.198>0.05$ sehingga model terbebas dari heteroskedastisitas. Dengan demikian dapat disimpulkan bahwa model tidak mengandung gejala heteroskedastisitas.
Tabel 9 : Uji t

\begin{tabular}{lllll}
\hline \multicolumn{1}{c}{} & & $\begin{array}{c}\text { Unstan } \\
\text { dardiz } \\
\text { ed } \\
\text { Coeffi } \\
\text { cients }\end{array}$ & & \\
\hline & & & \\
\hline 1 & $\begin{array}{l}\text { Con } \\
\text { stant }\end{array}$ & 1.278 & & \\
\hline & X1 & 0.373 & 3.320 & 0.003 \\
\hline & X2 & 1.287 & 2.730 & 0.011 \\
\hline
\end{tabular}

Sumber : Data diolah

Berdasarkan tabel di atas, nilai sig < 0.05. Dengan demikian, tingkat pendidikan dan pemahaman terhadap IF PSAK berpengaruh signifikan terhadap penyusunan dan penyajian laporan keuangan. Selain itu, berdasarkan nilai t, $26^{\text {di }}$ mana $x 1$ sebesar 3.320, dan t tabel


demikian dapat disimpulkan bahwa tingkat pendidikan berpengaruh positif terhadap penyusunan dan penyajian laporan keuangan.

Nilai $x 2$ sebesar 2.730 dan $t$ tabel sebesar 2.052. $t$ hitung $>\mathrm{t}$ tabel. Dengan demikian dapat disimpulkan bahwa tingkat pemahaman terhadap PSAK berpengaruh positif terhadap penyusunan dan penyajian laporan keuangan.

\section{Uji F}

Uji $\mathrm{F}$ digunakan untuk mengetahui ketepatan model (Suliyanto, 2011). Uji ini digunakan untuk mengetahui nilai prediksi dalam regresi yang mampu menggambarkan kondisi sesungguhnya. Hipotesis yang diajukan untuk uji $\mathrm{F}$ ini sebagai berikut :

$$
\begin{aligned}
& \mathrm{H}_{\mathrm{o}}=\text { jika } \mathrm{F} \text { hitung } \leq \mathrm{F} \text { Tabel, maka } \\
& \text { persamaan regresi atau model } \\
& \text { kurang tepat } \\
& \mathrm{H}_{\mathrm{a}}=\quad \text { jika } \mathrm{F}_{\text {hitung }}>\mathrm{F}_{\text {Tabel, }} \text {, maka }
\end{aligned}
$$

\section{Uji Hipotesis}

Uji $t$ 
$\begin{array}{clcr} & \text { akademisi dan } & \text { korporasi } & \text { yang } \\ \text { Tabel } 10 & \text { berkepentingan } & \text { sekali } & \text { dengan } \\ \text { Uji } F & \text { penyusunan dan } & \text { penyajian } & \text { laporan }\end{array}$ keuangan. Sementara itu, untuk entitas

\begin{tabular}{clllll}
\hline $\begin{array}{c}\text { Mode } \\
1\end{array}$ & & $\begin{array}{l}\text { Sum of } \\
\text { Square }\end{array}$ & $F$ & $\mathrm{~F}_{\text {tabel }}$ & S \\
\hline 1 & $\begin{array}{l}\text { Regre } \\
\text { ssion }\end{array}$ & 52.069 & 10.966 & 3.354 & 0.00 \\
\hline & $\begin{array}{l}\text { Resid } \\
\text { ual }\end{array}$ & 64.100 \\
\hline \multicolumn{5}{l}{ Total 116.168} \\
\hline & Sumber : Data diolah \\
\hline
\end{tabular}

Berdasarkan tabel tersebut, diperoleh nilai $\mathrm{F}$ tabel sebesar 10.966 dan F tabel sebesar 3,354. Karena Nilai $\mathrm{F}$ hitung $>\mathrm{T}$ tabel, Ha dapat diterima, di mana persamaan regresi memenuhi kriteria ketepatan. Selain itu, uji F ini dapat menyimpulkan bahwa variabel independen yaitu tingkat pendidikan dan tingkat pemahaman terhadap SAK berpengaruh secara simultan terhadap penyusunan dan penyajian laporan keuangan.

\section{Kesimpulan}

Rata-rata tingkat pendidikan penyusun dan pelapor laporan keuangan pada entitas masjid berada pada level SMA. Disamping itu, dilihat dari sisi usia, rata-rata berada di atas 45 tahunan. Tingkat pendidikan ini sangat mempengaruhi pengetahuan dan pemahaman akan akuntansi. Meskipun pada level SMA telah diberikan pembelajaran tentang akuntansi, namun terkait dengan entitas nirlaba baru disampaikan pada level perkuliahan.

Pernyataan Standar Akuntansi Keuangan (PSAK) merupakan standar penyusunan dan penyajian laporan keuangan. Standar ini dikeluarkan oleh Ikatan Akuntan Indonesia. Untuk entitas nirlaba seperti masjid, diatur dalam PSAK No. 45 dan SAK ETAP.

Sosialisasi terkait dengan PSAK ini memang terbatas biasanya di lingkungan masjid, dikarenakan kurangnya

Sigsosialisasi, sehingga tingkat pemahaman terhadap PSAK sangat rendah sekali. Rata-rata responden menjawab sangat tidak paham atau tidak paham. Hal ini tentu wajar adanya. Disamping masalah sosialisasi di atas, entitas masjid belum ditutut secara regulasi untuk menyusun laporan keuangan berdasarkan SAK.

Hal ini terbukti di lapangan di mana entitas masjid melaporkan laporan keuangannya menggunakan sistem single entry. Sistem ini hanya mencatat sisi penerimaan dan pengeluaran dan saldo kas, sehingga tidak mencerminkan aset sesungguhnya.

Secara umum penyusunan dan penyajian laporan keuangan di entitas masjid masih menggunakan sistem singel entry. Sistem ini hanya mencatat penerimaan dan pengeluaran. Dengan demikian, secara umum belum ditemukan laporan posisi keuangan, laporan kinerja dan laporan arus kas. Sistem pencatatan seperti ini, belum mengacu kepada standar pelaporan keuangan yang dikeluarkan oleh Ikatan Akuntan Indonesia (IAI) seperti yang tertuang dalam PSAK 45. Hal ini wajar adanya, mengingat pemahaman terhadap PSAK sendiri masih banyak yang belum mengetahui dan memahaminya. Untuk laporan penerimaan dan pengeluaran zakat pada dasarnya beberapa masjid sudah sesuai dengan PSAK 109.

Berdasarkan hasil pengolahan data dan uji hipotesis, tingkat pendidikan dan tingkat pemahaman terhadap PSAK berpengaruh secara signifikan terhadap penyusunan dan penyajian laporan keuangan entitas nirlaba. Pengaruh ini dapat kita liat pada koefisien tingkat pendidikan sebesar 0.373 dan koefisien tingkat pemahaman PSAK sebesar 1.287. Nilai signifikansi kedua variabel 
lebih kecil dari 0.05 yaitu masingmasing 0.003 dan 0.011 .

Tingkat pendidikan dan pemahaman ini, berkontribusi sebesar $40.7 \%$ terhadap eksistensi laporan keuangan entitas nirlaba. Meskipun kontribusi ini tidak melebihi $50 \%$, namun keduanya signifikan. Sementara itu, $59.3 \%$ dikontribusikan oleh faktor-faktor lain yang tidak diteliti dalam penelitian ini.

Penelitian ini memberikan reinforcement bahwa semakin tinggi pendidikan penyusun dan penyaji laporan keuangan, akan memberikan efek yang berbeda terhadap penyusunan dan penyajian laporan keuangan, begitu juga dengan adanya pemahaman yang baik terkait dengan PSAK. Sehingga, kedua variabel tersebut perlu diperhatikan dalam menyusun dan menyajikan laporan keuangan entitas masjid.

\section{Referensi}

Andarsari, Pipit Rosita. 2016. Laporan Keuangan Organisasi Nirlaba Entias Masjid. Ekonika. Vol. I No. 2, hal $143-152$

Anthony, Robert N. dan David W. Young. 2003. Management Control in Nonprofit Organization. USA: Mc-GrawHill Irwin.

Bastian, Indra. 2007. Akuntansi untuk LSM dan Partai Politik. Jakarta: Penerbit Erlangga.

Bastian, Indra. 2010. Akuntansi Sektor Publik, Suatu Pengantar. Jakarta: Penerbit Erlangga.

Dewan Standar Akuntansi Keuangan. 2011. Pernyataan Standar Akuntansi Keuangan Nomor 45 Pelaporan Keuangan Organisasi Nirlaba. Jakarta: IAI.
Dewan Standar Akuntansi Keuangan. 2011. Pernyataan Standar Akuntansi Keuangan Nomor 01 Kerangka Dasar Penyusunan dan Penyajian Laporan Keuangan. Jakarta: IAI.

Dewan Standar Akuntansi Keuangan. 2011. Pernyataan Standar Akuntansi Keuangan Nomor 109 Akuntansi Zakat, Infaq dan Shadaqoh. Jakarta: IAI.

Undang-Undang Nomor 16 Tahun 2001 tentang Yayasan

Financial Accounting Standards Board. 1980. Statements of Financial Accounting Concepts No. 4 Objectives of Financial Reporting by Nonbusiness Organization. USA: FASB

Hasibuan, David. 2010. Penerapan PSAK No. 45 Pada Yayasan Mandiri Anak Bangsa Nusantara Dalam Kaitannya Dengan Kualitas Informasi Pelaporan Keuangan. Jurnal Ilmiah Kesatuan Nomor 1 Volume 12, April 2010. STIE Kesatuan. Bogor. Hal. 25-30. https://www.google.com/url?sa=t $\& r c t=j \& q=\&$ esrc $=s \&$ source $=$ web \&cd $=1 \&$ cad $=$ rja\&ved $=0 C C o$ QFjAAurl=http\%3A\%2F\%2Fjurn al.stiekesatuan.ac.id\%2Findex.php $\% 2$ Fjik\%2Farticle\%2Fdownload $\% 2 F 32 \% 2 F 346 \& e i=X O K F U$ U oiIrQffsYD4Bw\&usg $=A F Q j C N H$ UUmFsfW22gMunMcpzBUHAlTv $Y R w \quad \& b v m=b v .56643336$, d.bmk. Diakses: Januari, 14, 2017

Nickels, William G., McHugh, James M., McHugh, Susan M. 2009. Pengantar Bisnis - Understanding Business. Buku 1. Edisi 
Kedelapan. Salemba Empat. Jakarta.

Mahsun, M. 2006. Pengukuran Kinerja Sektor Publik. Grafindo. Jakarta.

Mamesah, Melisa. 2013. Penerapan PSAK 45 pad GMIM Efrata Sentrum Sonder Kaitannya dengan Kualitas Informasi Laporan Keuangan. Jurnal EMBA Vol. 1 No. 4 Desember 2013, Hal. 17171728

Mooney, D.James. 1996. Konsep Pengenbangan Organisasi Publik. Bandung: Sinar Baru Algesindo.

Nainggolan, P. 2005. Akuntansi Keuangan Yayasan dan Lembaga Nirlaba Sejenis. PT. Raja Grafindo. Jakarta

Poerwadarmita. 2006. Kamus Umum Bahasa Indonesia. Pusat Bahasa Departemen Pendidikan Nasional. Edisi Ketiga. Balai Pustaka.

Rizky, Diyani Ade dan Yazid Yud Padmono. 2013. Analisis Penerapan PSAK 45 pada Yayasan Masjid Al Falah Surabaya. Jurnal Ilmu dan Riset Akuntansi. Vol 2. No. 7, hal 1-17.

Setiawan. 1992. Aneka Masalah Hukum dan Hukum Acara Perdata. Alumni. Bandung.

Wilson, Earl R. dan Susan C. Kattelus. 2002. Accounting for Governmental and Nonprofit Entities. USA: Mc GrawHill-Irwin Companies. Inc. 